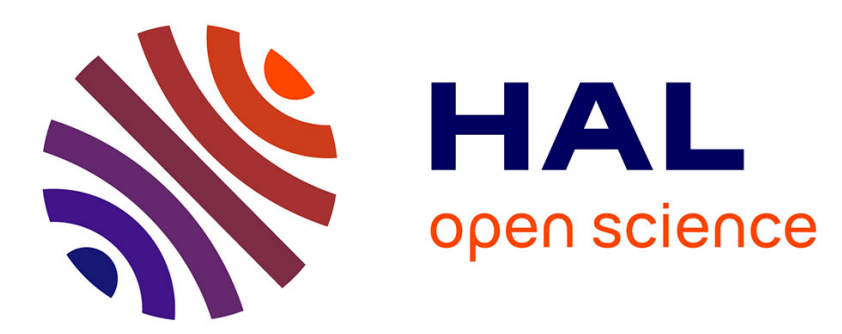

\title{
Massive hemoptysis due to a candida-related pulmonary artery pseudoaneurysm
}

\author{
Elsa Labat, Marc-Antoine Benderra, Deborah Choukroun, Julien Lopinto, \\ Guillaume Voiriot
}

\section{- To cite this version:}

Elsa Labat, Marc-Antoine Benderra, Deborah Choukroun, Julien Lopinto, Guillaume Voiriot. Massive hemoptysis due to a candida-related pulmonary artery pseudoaneurysm. Intensive Care Medicine, 2019, 46 (7), pp.1470-1471. 10.1007/s00134-019-05881-x . hal-03268542

\section{HAL Id: hal-03268542 \\ https: / hal.sorbonne-universite.fr/hal-03268542}

Submitted on 23 Jun 2021

HAL is a multi-disciplinary open access archive for the deposit and dissemination of scientific research documents, whether they are published or not. The documents may come from teaching and research institutions in France or abroad, or from public or private research centers.
L'archive ouverte pluridisciplinaire HAL, est destinée au dépôt et à la diffusion de documents scientifiques de niveau recherche, publiés ou non, émanant des établissements d'enseignement et de recherche français ou étrangers, des laboratoires publics ou privés. 


\section{Massive hemoptysis due to a candida-related pulmonary artery pseudoaneurysm}

Elsa Labat (1), Marc-Antoine Benderra (1), Deborah Choukroun (2), Julien Lopinto (3), Guillaume Voiriot (3).

(1) Sorbonne Université, Assistance Publique - Hôpitaux de Paris, Service d'oncologie médicale et de thérapie cellulaire, Hôpital Tenon, Paris, France

(2) Sorbonne Université, Assistance Publique - Hôpitaux de Paris, Service d'anatomie et cytologie pathologiques, Hôpital Tenon, Paris, France

(3) Sorbonne Université, Assistance Publique - Hôpitaux de Paris, Service de médecine intensive réanimation, Hôpital Tenon, Paris, France

Corresponding author: Dr Guillaume Voiriot, Hôpital Tenon, 4 rue de la Chine, 75020 Paris, France. Tel: +33156016263. Fax: +33156016097. E-mail: guillaume.voiriot@aphp.fr.

Keywords: Critical care; invasive candidosis; thoracic surgery; hemoptysis; pulmonary artery aneurysm

A 34-year-old woman was admitted to our intensive care unit for massive hemoptysis after having received chemotherapy for a metastatic trophoblastic gestational tumor. A Candida albicans catheter-related bloodstream infection had been diagnosed within the preceding 3 months. After removal of the endovascular device, she received long-term caspofungin and anticoagulant therapy because of a right atrial thrombus and pulmonary thromboembolisms of right middle and lower lobes. Following admission for hemoptysis, thoracic CT-scan (Figure 1A) disclosed a partially thrombosed pulmonary artery pseudoaneurysm with extravasation of iodinated contrast media. Transcatheter embolotherapy of the pseudoaneurysm was immediately performed (Figure 1B), using more than 3 meters of coils (Figure 1C), achieving an immediate bleeding control. Direct examination of tracheal aspirate disclosed yeasts but culture was negative, and serum 1,3-beta-glucan exceeded $500 \mathrm{pg} / \mathrm{mL}$ (normal level $<6.0 \mathrm{pg} / \mathrm{mL}$ ). A right pneumonectomy was performed five days later, considering the high risk of bleeding recurrence. Lung pathology demonstrated a pseudoaneurysm of the right pulmonary artery, with an altered elastic layer of the parietal wall and a hemorrhagic mycetoma within lumen (Figure $2 A, 2 B$ ). Grocott stain revealed pseudohyphae and yeasts within mycetoma (Figure $2 C$ ). Here is reported the first case of Candida-related pulmonary artery pseudoaneurysm illustrated with radiological, histopathological and mycological pictures.

Word Count: 201

Figure 1.

A. Multiplanar reconstruction of thoracic CT-scan showing the large pulmonary artery pseudoaneurysm (blue star) with extravasation of iodinated contrast media (yellow arrow). B. Selective pulmonary artery angiogram showing the stagnation of the iodinated contrast media within the lumen (blue star) and its leakage around the pseudonaneurysm (yellow arrow). C. Pulmonary artery angiogram after occlusion with coils showing the pseudoaneurysm exclusion, without any residual leakage.

Figure 2.

Histopathological findings from right pneumonectomy, demonstrating: A. an alteration of the pseudoaneursym parietal wall and hemorragic mycetoma within the lumen (hematoxylin and eosin stain, low magnification); B. an alteration of the elastic layer of the pseudoaneurysm parietal wall (orcein stain, low magnification); and $\mathbf{C}$. pseudohyphae and yeasts within the mycetoma (Grocott stain, high magnification).

Abbreviations: $\mathrm{B}=$ bronchus, $\mathrm{EL}=$ elastic layer, $\mathrm{PA}=$ pulmonary arterial pseudoaneurysm, $\mathrm{W}=$ parietal wall. 
Figure 1.

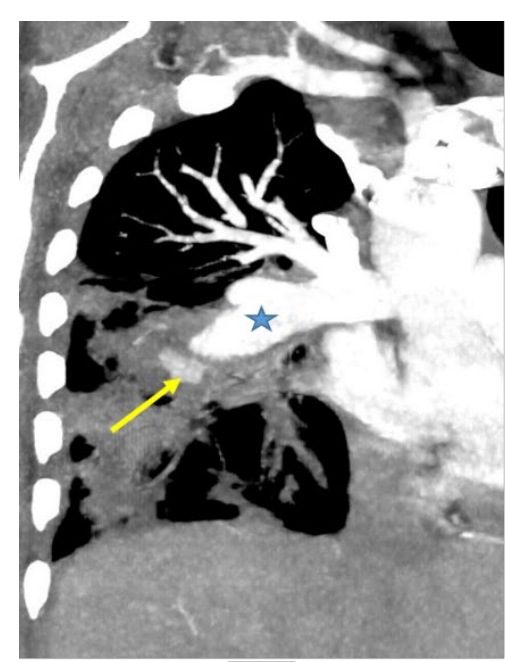

A

Figure 2.

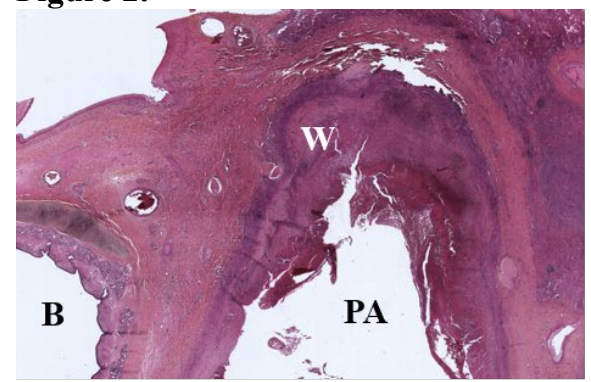

A

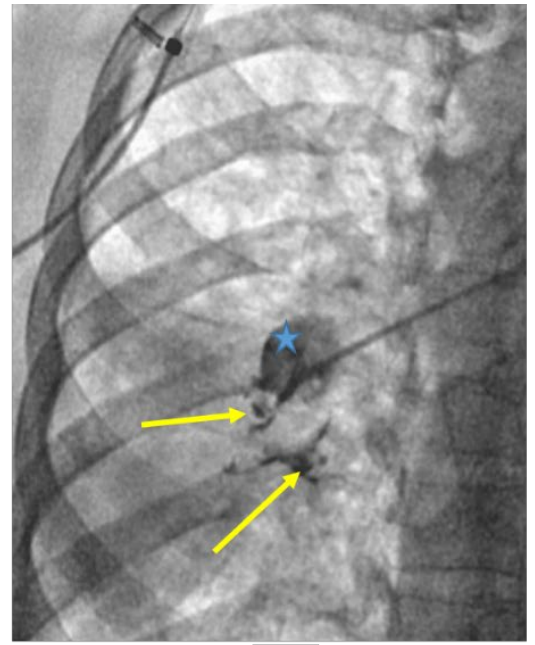

B

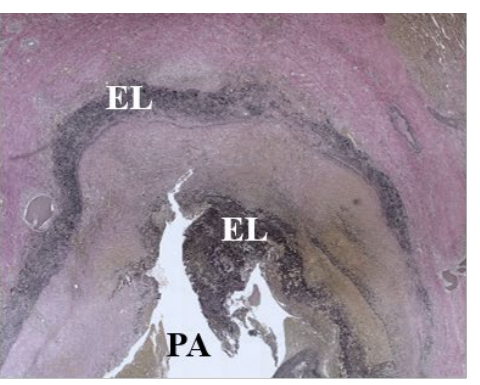

B
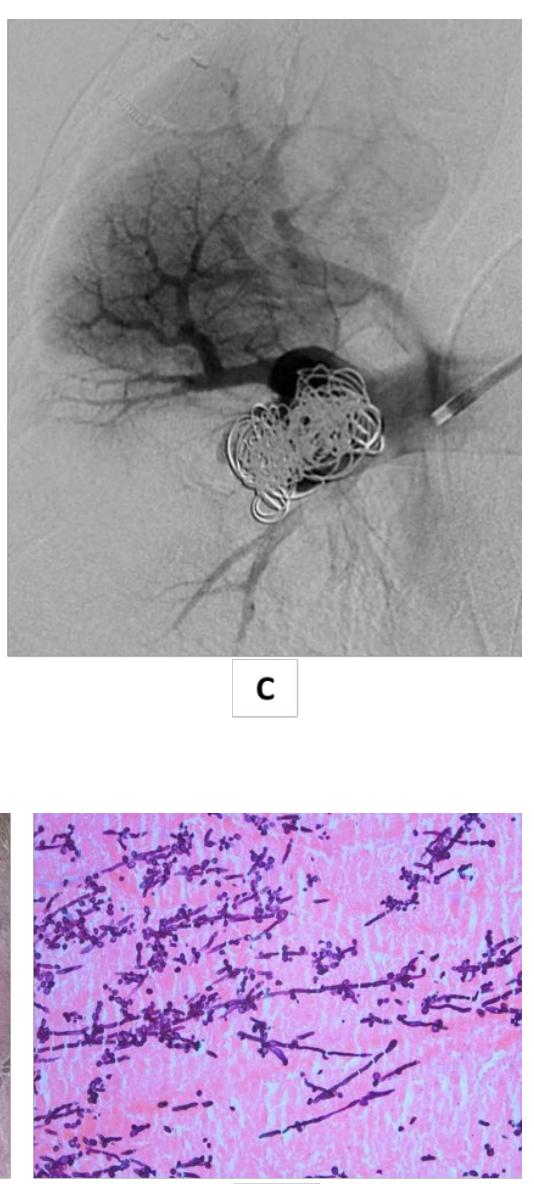

C 


\section{Author's contribution}

GV had full access to all the data and takes responsibility for the integrity of the data. EL drafted the manuscript. MAB participated in the images acquisition and helped to draft the manuscript. DC performed the histopathological examination. JL participated in the images acquisition and interpretation. GV revised the manuscript. All authors read and approved the final version to be submitted.

\section{Conflict of interest statements}

The authors have reported that no potential conflicts of interest exist with any companies/organizations whose products or services may be discussed in this article.

\section{Role of funding source}

No funding.

\section{Ethics}

Authors declare that the informed consent for publication has been obtained from the patient. 